\title{
Study of Temporal Variations in Physico-Chemical Parameters of Vembanad Lake at Panangad-Kumbalam region, Kochi, Kerala, India
}

\author{
K. Jyotsna Rajeswari ${ }^{1 *}$, G. Suresh ${ }^{2}$, P. Srikanth ${ }^{3}$ and N. N. Raman ${ }^{1}$ \\ ${ }^{1}$ Department of Aquatic Environment Management, Kerala University of Fisheries and Ocean \\ Studies, Panangad, Kochi, Kerala, India \\ ${ }^{2}$ Department of Aquaculture, College of Fishery Science, Muthukur, Nellore, Sri \\ Venkateswara Veterinary University, Tirupati, Andhra Pradesh, India \\ ${ }^{3}$ Department of Fisheries Engineering and Technology, Kerala University of Fisheries and \\ Ocean Studies, Panangad, Kochi, Kerala, India \\ *Corresponding author
}

\section{A B S T R A C T}

The present investigation has been carried out for determining the various physicochemical and biological parameters prevailing in Vembanad Lake of Panangad region, Kochi. The water samples were collected fortnightly from the Panangad-Kumbalam region for a period of ten months (September, 2015 to June, 2016). Meteorologically the whole

\section{Keywords}

Vembanad Lake,

Panangad-Kumbalam,

Water quality parameters,

physico-chemical

characteristics

\section{Article Info}

Accepted:

20 May 2018

Available Online:

10 June 2018 study period can be classified as South west monsoon (September, 2015), Post-monsoon (October -November, 2015), North east monsoon (December, 2015 to March 2016), Premonsoon (April May, 2016) and beginning of south west monsoon (June, 2016). The analysis showed that the mean maximum temperature was $30.75^{\circ} \mathrm{C}$ during post monsoon, the mean maximum $\mathrm{pH}$ was 7.99 during post monsoon, the mean maximum DO was $6.22 \mathrm{mg} / \mathrm{l}$ during post monsoon, the mean maximum alkalinity was $144.5 \mathrm{mg} / \mathrm{l}$ during south west monsoon, the mean maximum transparency was 73.37 during north east monsoon, the mean maximum nitrite was $1.48 \mathrm{mmol} / 1$ during south west monsoon (2015), the mean maximum nitrate was $1 \mathrm{mmol} / \mathrm{l}$ during south west monsoon (2016) and the mean maximum phosphate was $4.13 \mathrm{mmol} / 1$ during south west monsoon (2016) were recorded. Among phytoplankton diatoms are most dominant species in this region. Among zooplankton copepods are dominantly seen in the study region. Among aquatic weeds, Eichornia crassipes was dominantly seen in all the seasons. Five species of shellfishes are collected during the study period which are belongs to the order Decapoda. 24 species of fin fishes are collected during the study period from study area. The fishes can be categorized into eight orders and 18 families.

\section{Introduction}

Vembanad Lake is the largest in the state of Kerala and counted as one of the largest lakes in India with the maximum length and width of $96.5 \mathrm{~km}$ and $14 \mathrm{~km}$ respectively. It also sustains a large variety of fishery and is a cradle for many economically important migratory species (Walmiki et al., 2016). The evolutionary history of this lake shows that it 
plays an important role in the ecology and economy of the Southwest coast of India. The lake is bordered by Alappuzha, Kottayam, and Ernakulam districts. The lake is fed by 10 rivers flowing into it including the six major rivers of central Kerala namely the Achenkovil, Manimala, Meenachil, Muvattupuzha, Pamba, and Periyar. The remote forcing of the lake, influencing the formation of mud banks and other coastal processes invite scientific curiosity in characterizing the behavior of the lake with respect to physical and chemical properties and the associated biological productivity. The Vembanad Lake is presently undergoing severe environmental degradation due to increased human intervention. Recognizing the socio-economic importance of this water body, in 2002 it has been scheduled under Ramsar site No. 1214 at the Convention on Wetlands organized by the UNESCO in the Iranian city of Ramsar in 1981. High levels of pollution have been notified at certain hotspots of the Vembanad back waters. The lake is presently undergoing severe environmental crisis due to the unregulated anthropogenic activities that are disrupting thenatural ecological balance of this rich ecosystem (Mogalekaret al., 2015). It is very important to study physico-chemical factors, which influence the biological productivity of water body. The maintenance of a healthy aquatic ecosystem is dependent on the physicochemical properties of water and the biological diversity. Physico-chemical study could help in understanding the structure and function of particular water body in relation to its habitats. Physical properties such as temperature, light penetration, water movement play an important role in plankton distribution and lake stratification. Many fish processing plants, hotels, hospitals, industrial units etc. are situated at both banks of Vembanad Lake. The waste discharges from these establishments, without proper treatment might have deteriorated the quality of water.
Mass mortality of fishes and other organisms are frequently reported from the several hotspots of Vembanad Lake. The aim of present study is to assess the quality of water of Vembanad Lake near Panangad region, in Kumbalam sector.

\section{Materials and Methods}

The present investigation of the physicochemical and biological evaluation of Vembanad Lake is to understand the seasonal changes in the hydro biological conditions of Vembanad Lake in the Panangad-Kumbalam sector in Kochi.

The data was collected from the PanangadKumbalam region at an interval of fifteen days from September 2015 to June 2016. Total 20 visits were made during the study period. Surface water samples were collected from Panangad-Kumbalam between 6 am to $9 \mathrm{am}$. in three separate clean containers and labeled station wise to indicate date and location, brought to the laboratory and subjected to analysis immediately as for as possible. The parameters such as Water temperature was measured by using mercury thermometer and transparency was measured by using secchi disk. $\mathrm{pH}$ was estimated by using digital $\mathrm{pH}$ meter. Alkalinity and dissolved oxygen were estimated by titration method. Nitrate and phosphate were estimated by using spectrophotometer. Absorbance was measured at $540 \mathrm{~nm}$ and $680 \mathrm{~nm}$ respectively. Standard Methods for Estimation of Water and Waste Water $20^{\text {th }}$ Edition, APHA, AWWA, 2005 were referred for estimation of water quality parameters. The identification of zooplanktons was carried out in the laboratory under compound microscope by using keys and monographs of standard references (Pennak, 1978 and Lynne, 2004). Cast net, gillnet and Chinese dip net was used to catch fishes and shellfishes from Panangad-Kumbalam region. Aquatic plants available in the selected region 
were collected by hand picking and also with the help of scoop net.

\section{Statistical Analysis}

Statistical Analysis was carried out by using software package of SPSS 22. Pearson's correlation coefficient ( $r$ ) used to find out the relationship among different water quality parameters at $1 \%(* *)$ and $5 \%(*)$ level of significance.

\section{Results and Discussion \\ Hydrological Parameters}

\section{Water Temperature}

The average water temperature observed during the study period was $29.32^{\circ} \mathrm{C}$. The highest water temperature was observed during the second half of April $\left(32^{\circ} \mathrm{C}\right)$ and the lowest water temperature was observed during the first half of June $\left(27^{\circ} \mathrm{C}\right)$. The average highest water temperature was recorded during pre-monsoon $\left(30.75^{\circ} \mathrm{C}\right)$ and lowest during south-west monsoon of $2015\left(27.25^{\circ} \mathrm{C}\right)$ (Fig 2). Temperature showed positive correlation with $\mathrm{pH} \quad\left(\mathrm{r}=.799^{* *}\right)$ and Transparency $\left(\mathrm{r}=.516^{*}\right)$ and negatively correlated with DO (r=-.627**) and Nitrate $\left(\mathrm{r}=-.540^{*}\right)$ (Table 2). During SW-monsoon minimum temperature was recorded and there was a slight increase of temperature during post-monsoon period, which was then further increased during N-E monsoon and maximum during pre-monsoon, but decreased at the onset of monsoon. A Similar observation was made by Menon et al., (1971). Varma et al., (2002) and Haridevi et al., (2004) also reported similar trends in temperature. Jayasree (2009) observed that backwaters of Panangad region had a temperature range of $26^{\circ} \mathrm{C}$ to $32.5^{0} \mathrm{C}$ which is much matching with the range of present study. Sarmah, (2011) also found a sharp decline in temperature during the monsoon due to rains and high throughout the latter half of the post-monsoon and pre-monsoon due to summer season and less rainfall in Vembanad lake.

\section{pH}

During the study period, the average $\mathrm{pH}$ estimated was 7.69.The highest $\mathrm{pH}$ was recorded during the first half of May (8.18) and the lowest $\mathrm{pH}$ was recorded during the first half of September (7.05). The maximum average $\mathrm{pH}$ was recorded during pre-monsoon (7.9) and the minimum average $\mathrm{pH}$ was recorded during the SW-monsoon of 2015 (7.36) (Fig 3). pH is positively correlated with temperature $\left(.799^{* *}\right)$, alkalinity $\left(.576^{* *}\right)$ and transparency $\left(.494^{*}\right)$ and negatively correlated with DO $\left(-.849^{* *}\right)$ and nitrate $\left(-.540^{*}\right)$ (Table 2).In the present study the $\mathrm{pH}$ value was less during the SW-monsoon and it showed increasing trend in the selected region. The increasing trend continued during the post monsoon, North-East monsoon and reached maximum during the pre-monsoon. Jayasree. (2009) studied the structure and the seasonal changes of the macrobenthic community in relation to the Hydrography of a prawn filtration pond, near Panangad region of the Cochin backwater and found an increasing trend of $\mathrm{pH}$ from the post-monsoon to premonsoon season as in the case of present study. Joseph et al., (2011) reported that the $\mathrm{pH}$ of Cochin backwater was slightly alkaline and it ranged between 7.01 and 8.8 which is well within the range of present study. High $\mathrm{pH}$ is related to the season and day light. In the month of May summer is on its peak whereas, in the month of September the day light was less which may be the reason for the high and low $\mathrm{pH}$

\section{DO}

The average DO was estimated during the study period was $(5.188 \mathrm{mg} / \mathrm{l})$. The highest DO 
was observed during the second half of October $(7.2 \mathrm{mg} / \mathrm{l})$ and the lowest DO was observed during the second half of March $(3.8 \mathrm{mg} / \mathrm{l})$. The maximum average DO was recorded during SW-monsoon of 2015 (7 $\mathrm{mg} / \mathrm{l}$ ) and the minimum average DO was recorded during the pre-monsoon $(4.39 \mathrm{mg} / \mathrm{l})$ (Fig 4s). DO is positively correlated with nitrate $\left(.560^{*}\right)$ and negatively correlated with temperature $\left(-.627^{* *}\right), \mathrm{pH}\left(-.849^{* *}\right)$ alkalinity ($\left..653^{* *}\right)$ and transparency $\left(-.514^{*}\right)$ (Table 2). Dissolved oxygen reflects the water quality status and physical and biological processes in water and show the metabolic balance of a lake. Dissolved oxygen is an important water quality parameter in assessing water pollution (Laluraj et al., (2002). It showed slight decrease in DO from SW-monsoon to postmonsoon and from post-monsoon to premonsoon, again it showed decreasing trend. It increases from pre-monsoon and reached maximum during SW-monsoon. Saraladevi et al., (1979) remarked that DO was higher during the monsoon and was lower during the pre-monsoon and post-monsoon, present study also showing similar trend. High DO was found due to the presence of abundance phytoplankton in water and minimum was found due to high evaporation.

\section{Alkalinity}

Alkalinity of water is very important which influence the productivity of an ecosystem. The average alkalinity was observed during the study period was 116.2. The highest alkalinity was observed during the second half of June (149) and the lowest alkalinity was observed during the second half of September (85). The maximum average alkalinity was recorded during SW-monsoon-2016 (144.5) and the minimum average alkalinity was recorded during the SW-monsoon of 2015 (87.5) (Fig 5). Alkalinity showed the positive correlation with $\mathrm{pH}\left(.576^{* *}\right)$ and negative correlation with DO $\left(-.653^{* *}\right)$ (Table 2). In
Panangad-Kumbalam region the mean maximum temperature was in SW-monsoon, this region showed on increasing trend by the end of SW-monsoon to post-monsoon, NEmonsoon, Pre-monsoon and maximum during the onset of monsoon. Similar trend had been reported by silas and pillai (1975). Joseph et al., (2008) reported that the alkalinity of Cochin estuary ranged between 18 and 217 $\mathrm{CaCo} 3 / 1$, which is similar to the present study. Devi (2009) studied about the physicochemical properties of the Cochin backwater of Panangad region and recorded minimum total alkalinity during SW-monsoon season and increased value in post-monsoon and premonsoon. She estimated a maximum value of 200 mg CaCo3/l.

\section{Transparency}

Factors affecting the transparency of the water in the pond are silt, microscopic organisms and suspended organic matter (Combie, 1953). The lower values of transparency might be due to turbidity caused by eroded soil and higher values during post-monsoon period may be due to lesser turbulence and decantation of suspended particles. The average transparency was observed during the study period was $62.9 \mathrm{~cm}$. The highest transparency was observed during the first half of March $(88 \mathrm{~cm})$ and the lowest transparency was observed during the first and second half of June $(50 \mathrm{~cm})$. The maximum average transparency was recorded during north-east monsoon $(73.5 \mathrm{~cm})$ and the minimum average transparency was recorded during the SWmonsoon of $2016 \quad(50 \mathrm{~cm})$ (Fig 6). Transparency showed positive correlation with water temperature $\left(.516^{*}\right)$ and $\mathrm{pH}\left(.494^{*}\right)$ and negatively correlated with DO $\left(-.514^{*}\right)$ (Table $2)$. In the present investigation the highest transparency recorded during the NE-monsoon and lowest transparency during the SWmonsoon. It showed increasing trend in post monsoon period and further increased in NE- 
monsoon and again it started decreasing during post-monsoon. Chhaya et al., (2007) recorded the minimum transparency during rainy season and maximum during winter. Manjare et al., (2010) also reported similar observations from different water bodies in Maharashtra.

\section{Nitrite}

The average nitrite, estimated during the study period, was $1.55 \mathrm{mmol} / \mathrm{l}$. The highest nitrite was observed during the first half of April $(2.9 \mathrm{mmol} / \mathrm{l})$ and the lowest nitrite was observed during the second half of December $(0.49 \mathrm{mmol} / \mathrm{l})$. The maximum average nitrite was recorded during pre-monsoon $(2.31 \mathrm{mmol} / \mathrm{l})$ and the minimum average nitrite was recorded during the post-monsoon (1.16mmol/l) (Fig 7). The lower values of transparency might be due to turbidity caused by eroded soil and higher values during postmonsoon period may be due to lesser turbulence and decantation of suspended particles. The nitrite was showed decreasing trend in post-monsoon and it started increase in NE-monsoon and reached maximum during Pre-monsoon. Varadharajan (2014) recorded the minimum nitrite of $0.374 \mathrm{mmol} / 1$ during the summer period in the months of May and April and maximum of $2.674 \mathrm{mmol} / \mathrm{l}$ and
$2.598 \mathrm{mmol} / 1$ were recorded during the monsoon season in the month of November which is comparable with the present observation.

\section{Nitrate}

The average nitrate was estimated during the study period was $10.8 \mathrm{mmol} / \mathrm{l}$. The highest nitrate was estimated during the first half of September $(18.03 \mathrm{mmol} / \mathrm{l})$ and the lowest nitrate was estimated during the first half of December $(6.50 \mathrm{mmol} / \mathrm{l})$. The maximum average nitrate was recorded during SWmonsoon-2015 (17mmol/l) and the minimum average nitrate was recorded during the NEmonsoon (9.41mmol/l) (Fig 8). Nitrate showed positive correlation with DO $\left(.560^{*}\right)$ and negative correlation with temperature ($\left..540^{*}\right)$ and $\mathrm{pH}\left(-.540^{*}\right)$ (Table 2). In the present study maximum nitrate was recorded during the SW-monsoon period and minimum during the NE-monsoon. Nitrate showed decreasing trend during the post monsoon and it continued in NE-monsoon and it showed a slight increase in Pre-monsoon. Sankaranarayanan and Qasim (1969) stated that generally, the amount of nitrite in the sea is less as compared to that of nitrate and ammonia, although in temperate waters it showed a slight increase in winter.

Fig.1 Location of Panangad-Kumbalam region where the samples were collected
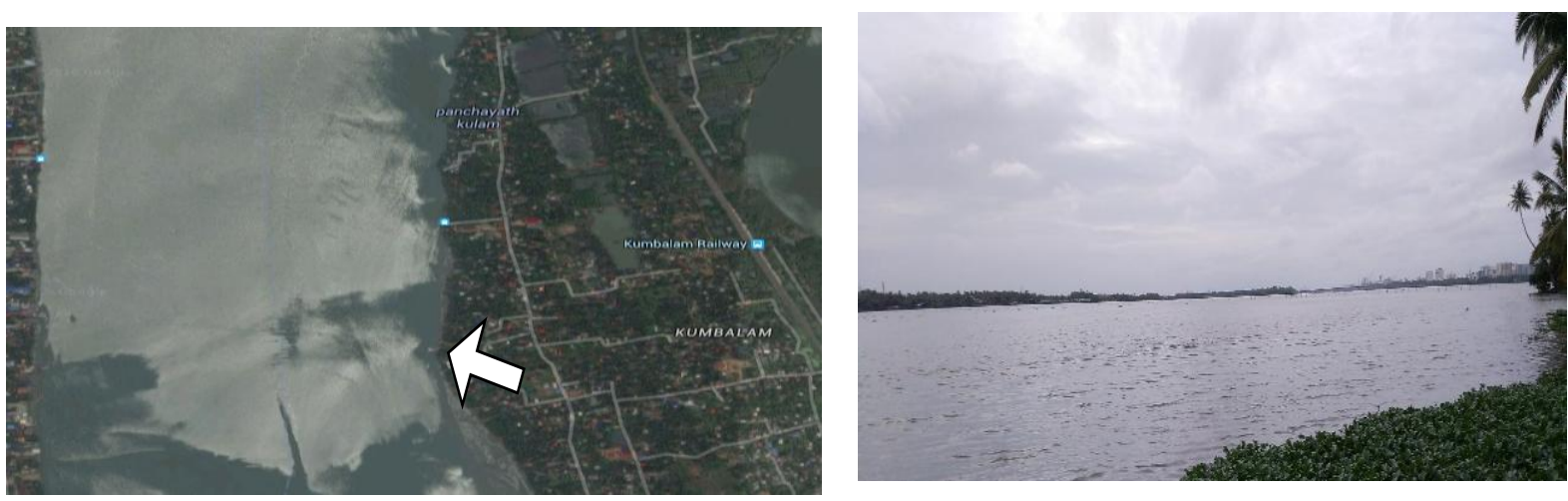
Fig.2 Seasonal variation in Temperature

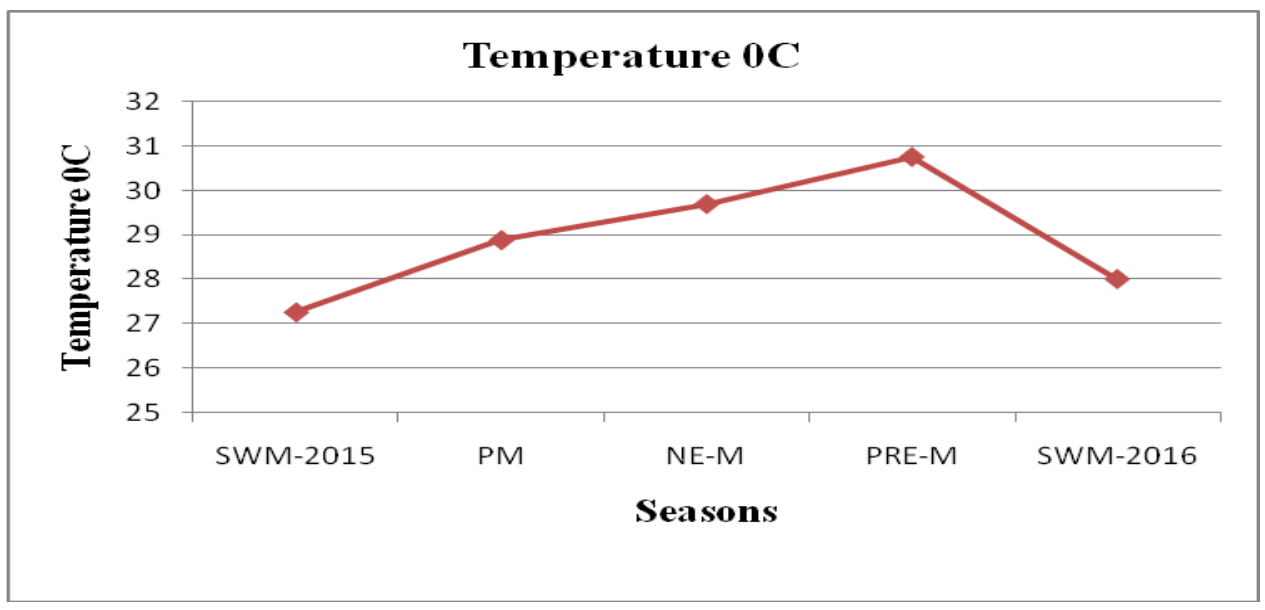

Fig.3 Seasonal variation in $\mathrm{pH}$

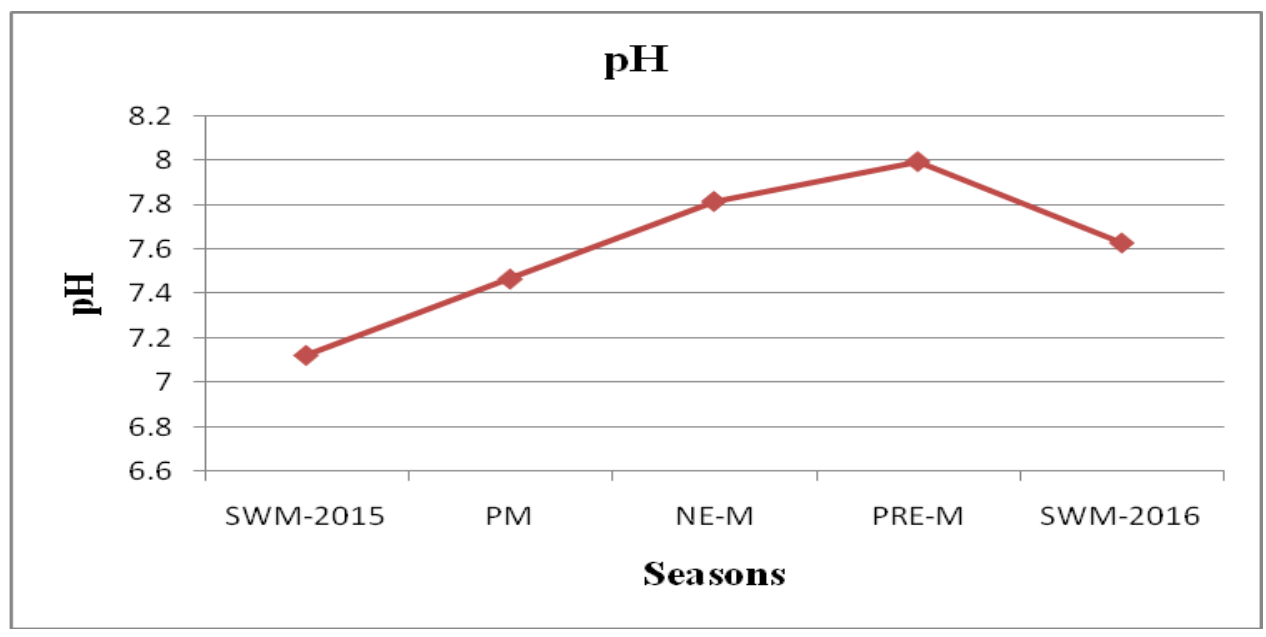

Fig.4 Seasonal variation in DO

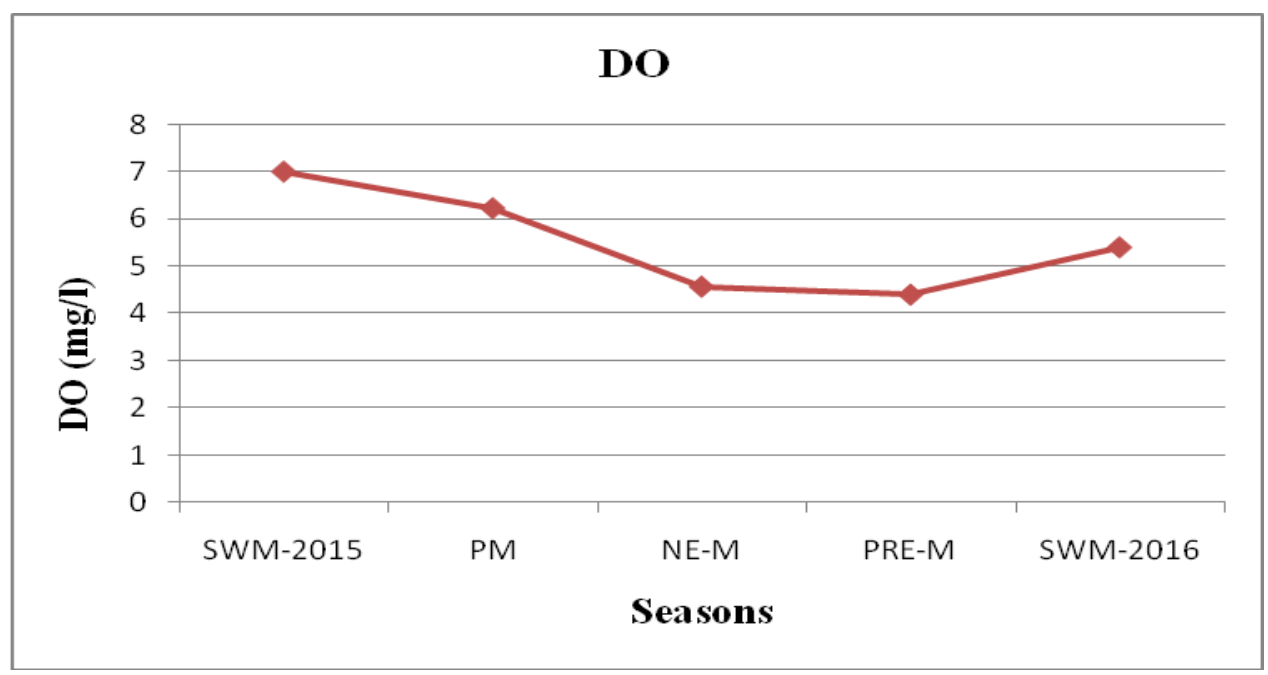


Fig.5 Seasonal variation in Alkalinity

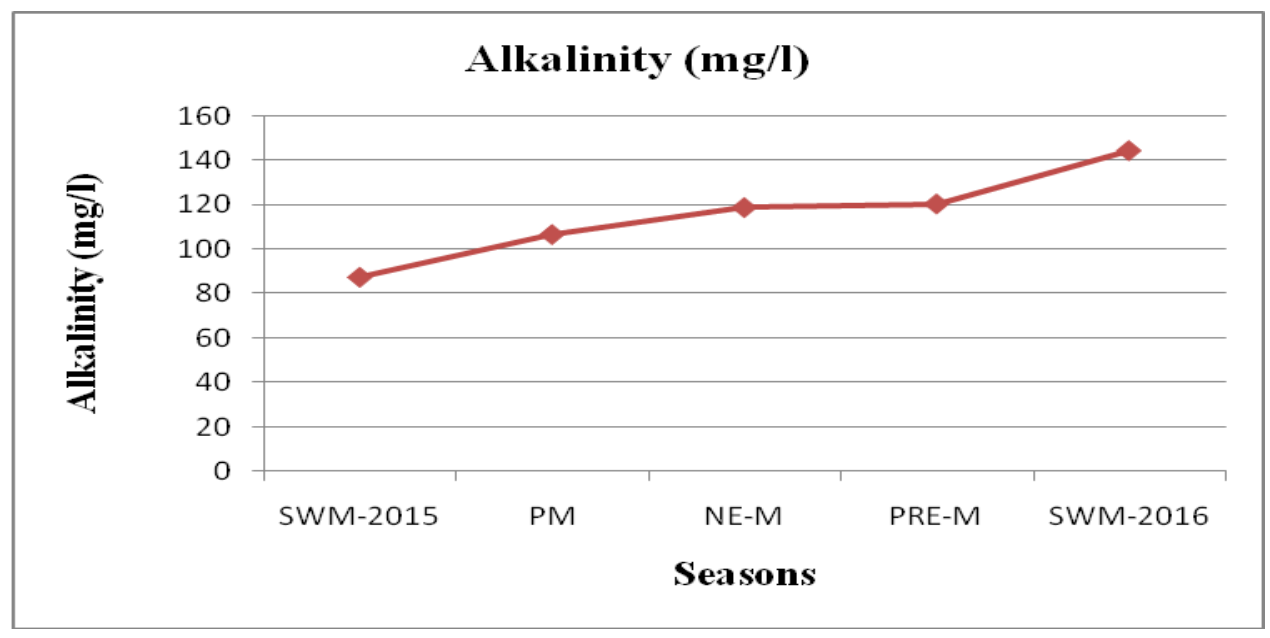

Fig.6 Seasonal variation in Transparency

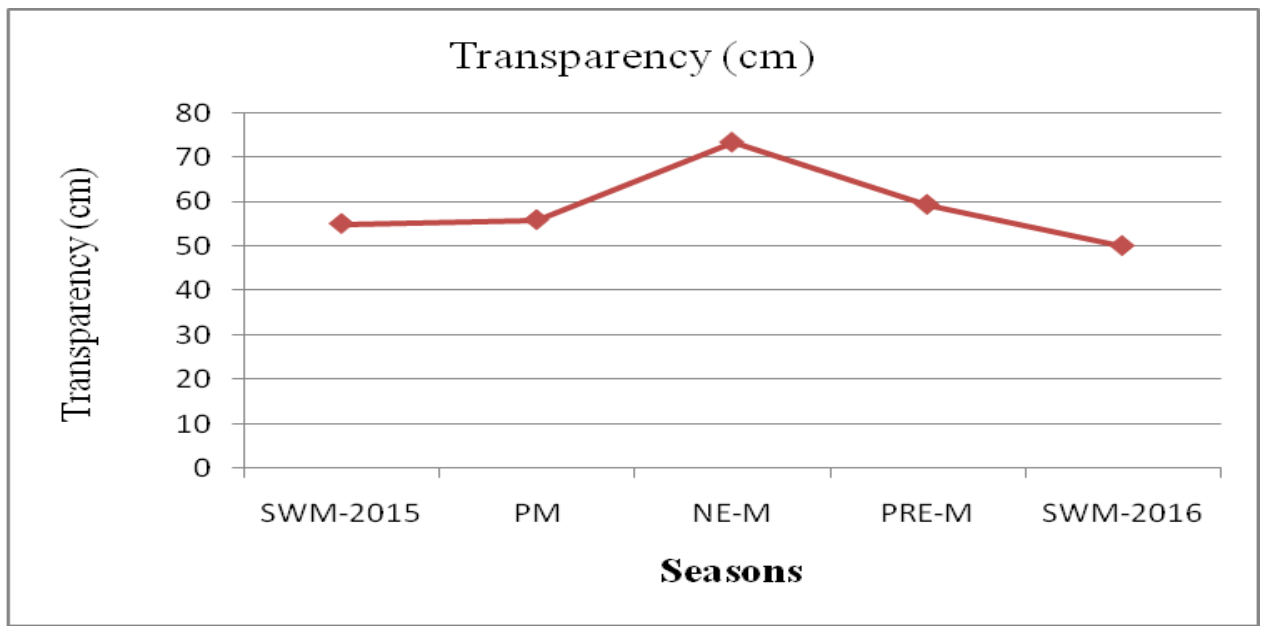

Fig.7 Seasonal variation in Nitrite

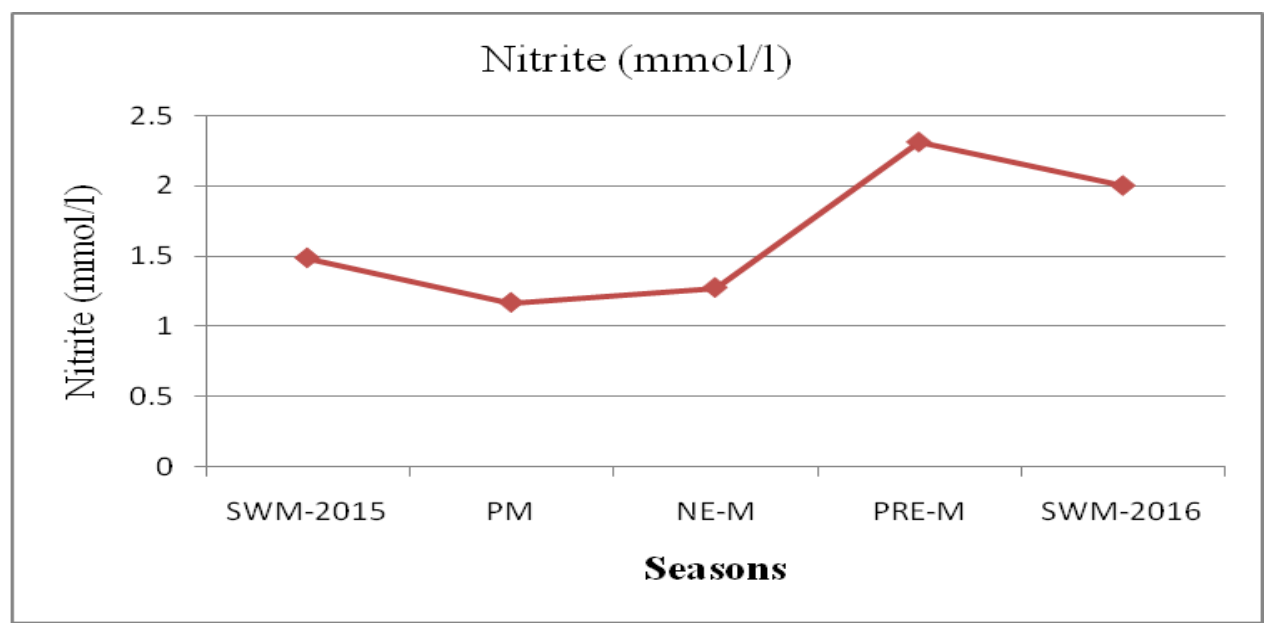


Fig.8 Seasonal variation in Nitrate

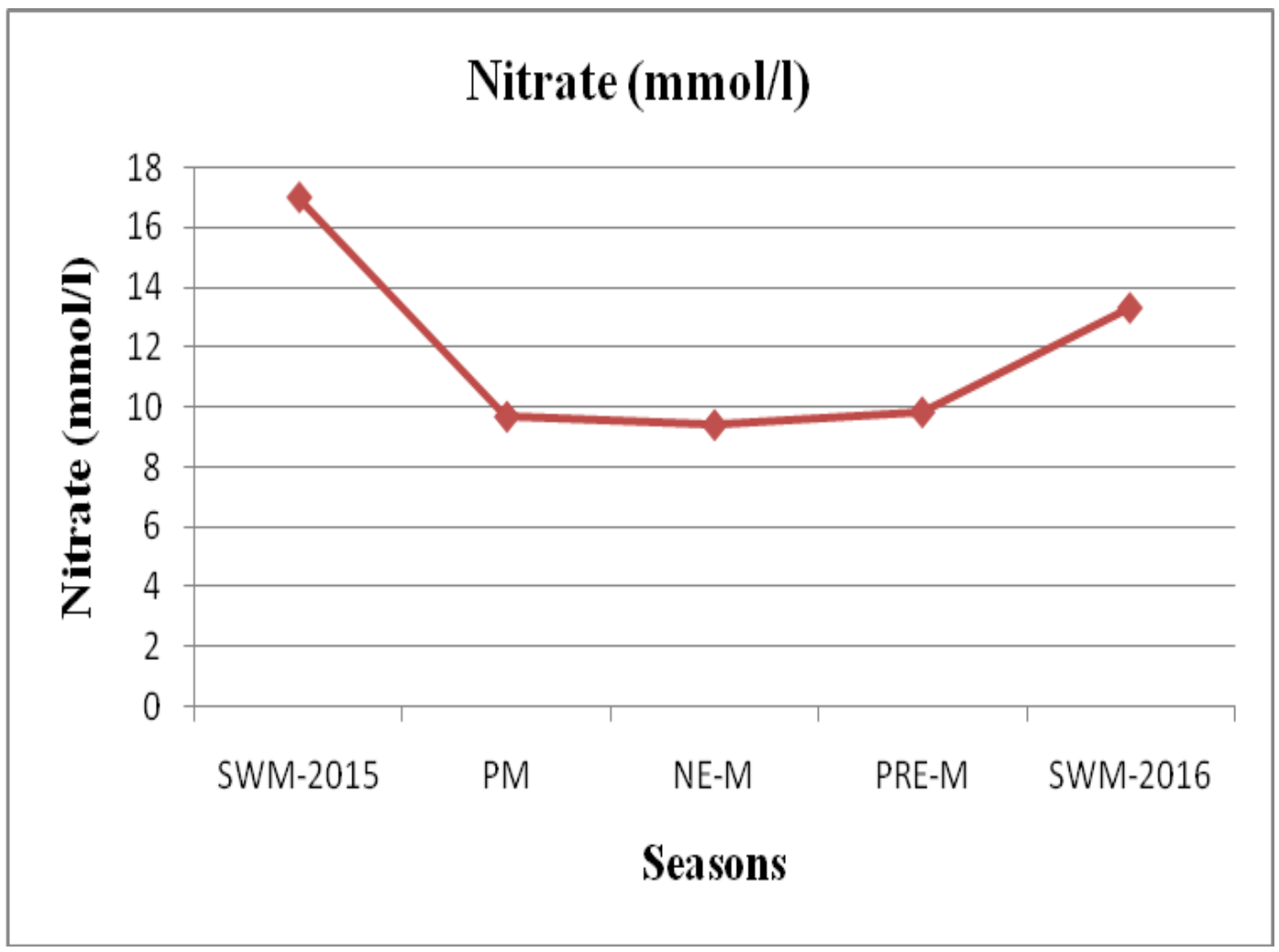

Fig.9 Seasonal variation in Phosphate

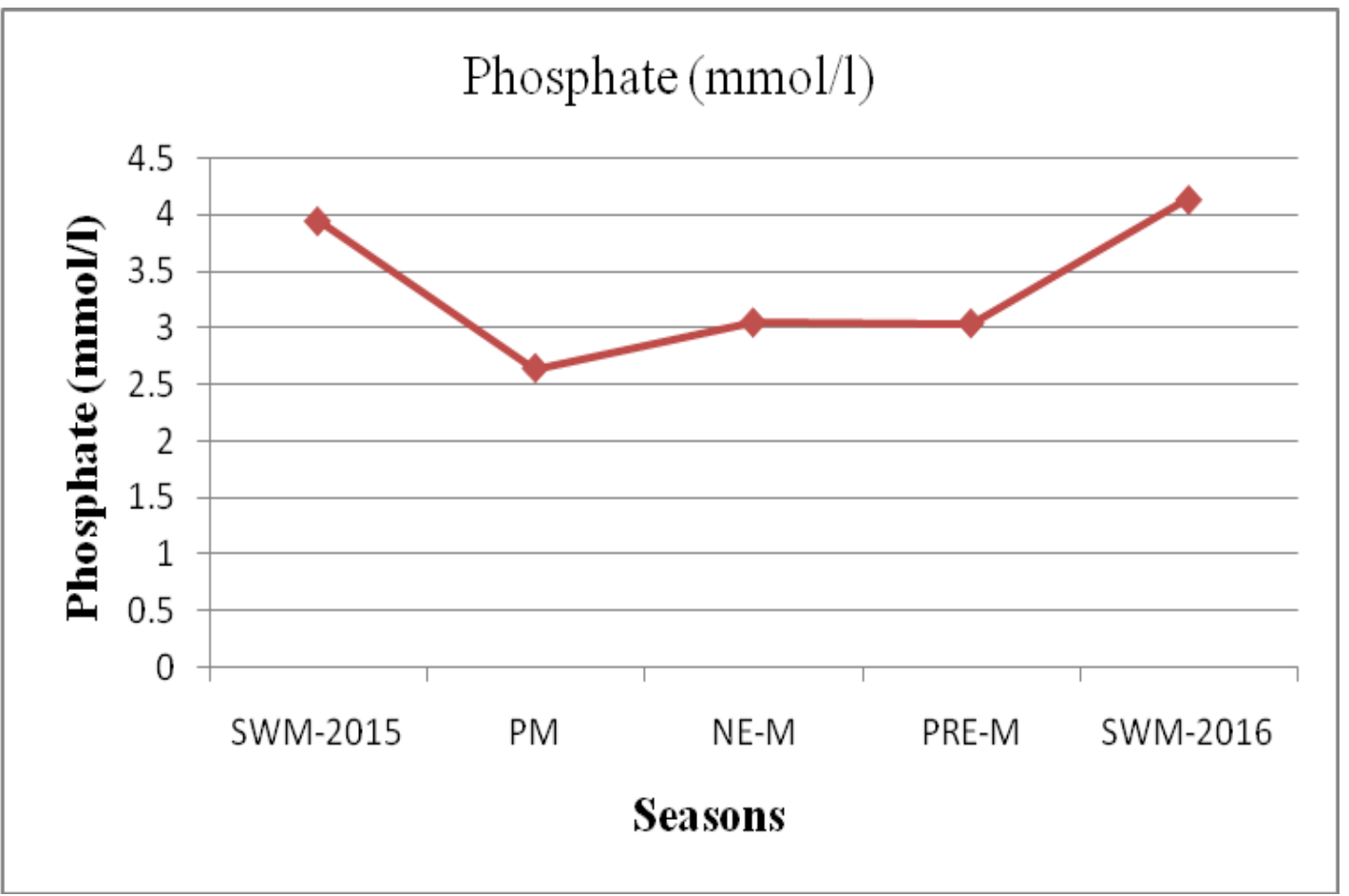


Fig.10 Phytoplankton observed during the study period at Panangad-Kumbalam region
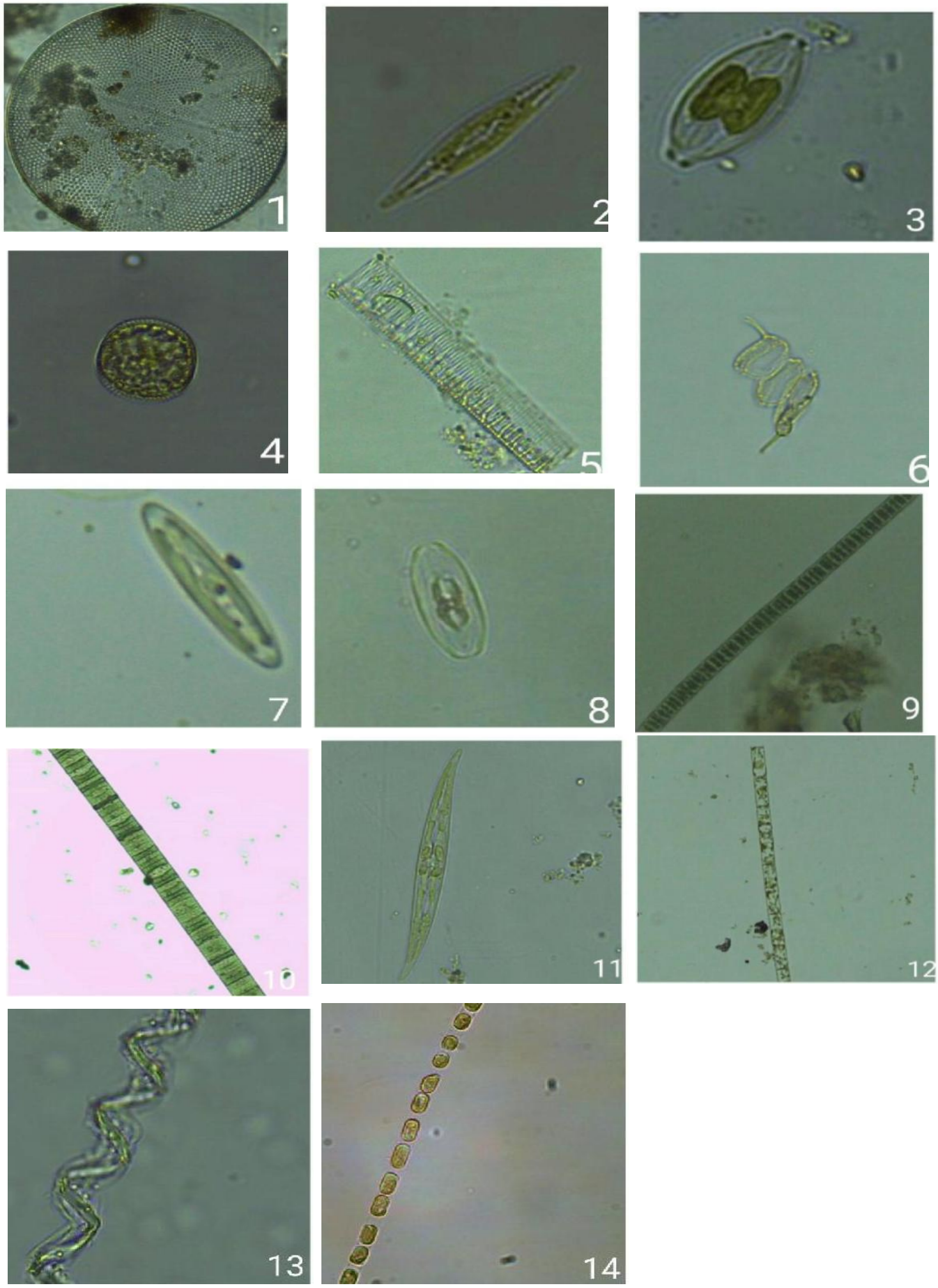

1) Cosinodiscus spp. 2) Navicula spp. 3) Amphora bioculate 4) Thalasiossira decipiens 5) Fragilariopsis spp. 6) Scenedesmus spp. 7) Nitzshia scaplliformis 8) Amphora lineolata 9) Lyngbya sp. 10) Oscillatoria spp. 11) Pleurosigma spp. 12) Leptocylindrus danicus. 13) Spirulina spp. 14)Skeletonema spp. 
Fig.11 Zooplankton observed during study period at Panangad-Kumbalam region
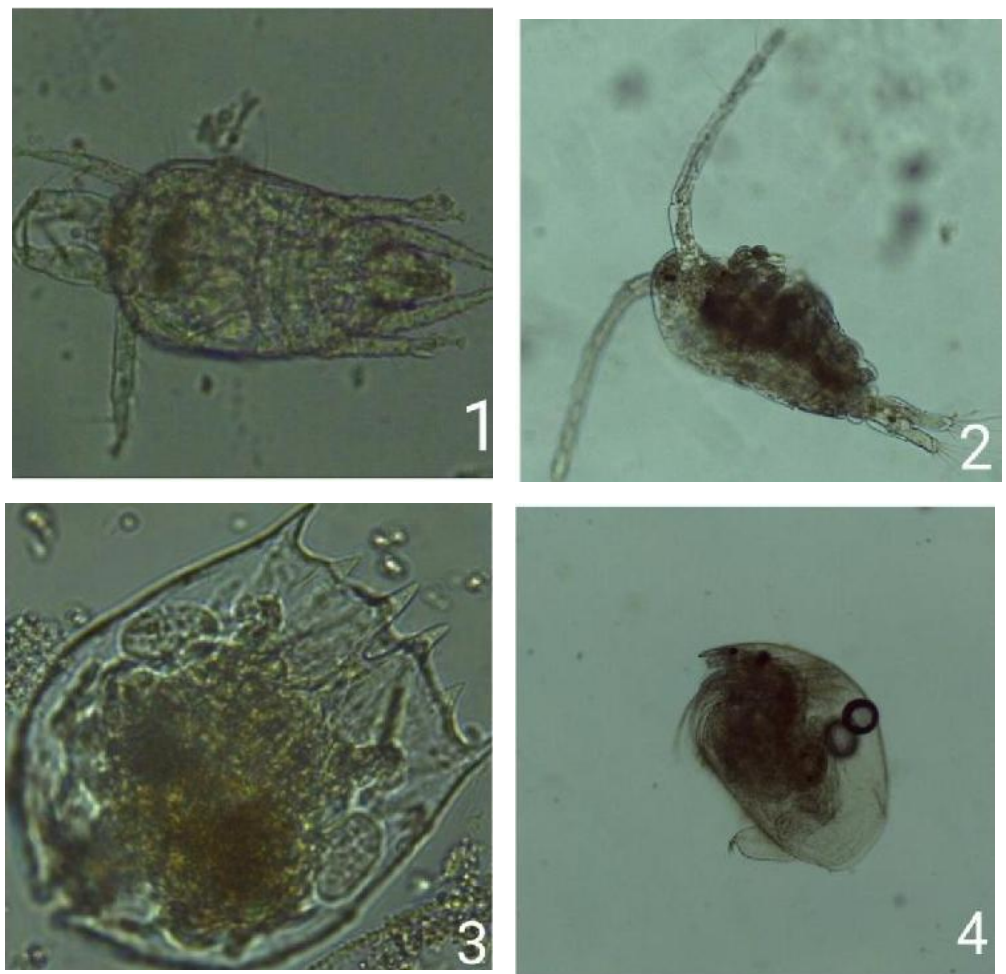

1. Copepod nauplius 2. Copepod 3. Rotifers 4. Cladocera (Daphnia)

Table.1 List of Fishes and Shellfishes found during the study period

\begin{tabular}{|l|}
\hline S. No \\
\hline 1 \\
\hline 2 \\
\hline 3 \\
\hline 4 \\
\hline 5 \\
\hline 6 \\
\hline 7 \\
\hline 8 \\
\hline 9 \\
\hline 10 \\
\hline 11 \\
\hline 12 \\
\hline 13 \\
\hline 14 \\
\hline 15 \\
\hline 16 \\
\hline 17 \\
\hline 18 \\
\hline 19 \\
\hline 20 \\
\hline 21 \\
\hline 22 \\
\hline 23 \\
\hline 24 \\
\hline
\end{tabular}

\begin{tabular}{l} 
Common name \\
Indian Mackeral \\
Ponyfish \\
Indian oil sardine \\
Pearl spot \\
Tilapia \\
Milkfish \\
Mullet \\
Boal \\
Indian butter catfish \\
Snakehead murrel \\
Dwarf Snakehead \\
Tank goby \\
Red snapper \\
Threadfin Sea Catfish \\
Stinging cat fish \\
Long Whiskers catfish \\
Scat \\
\hline Catla \\
\hline Rohu \\
Bengal tonguesole \\
Mud crab \\
Giant fresh water prawn \\
Green Tiger Prawn \\
Indian White Shrimp \\
\hline
\end{tabular}

\begin{tabular}{l} 
Scientific name \\
\hline Rostrelliger kanagurta \\
\hline Secutor ruconius. \\
\hline Sardinella longiceps \\
\hline Etroplus suratensis \\
Oreochromis spp. \\
\hline Chanos chanos \\
\hline Mugil cephalus \\
\hline Wallago attu \\
\hline Ompok bimaculatus \\
\hline Channa striatus \\
\hline Channa gachua \\
\hline Glassogobius giuris \\
\hline Lutjanus argentimaculaus. \\
\hline Arius arius \\
\hline Heteropneustus fossilis \\
\hline Mystius guilo \\
\hline Scatophagus argus \\
\hline Catla catla \\
\hline Labeo rohita \\
\hline Cynoglossus cynoglossos \\
\hline Scylla serrata \\
\hline Macrobrachium rosenbergii \\
\hline Penaeus semisulcatus \\
\hline Feneropenaeus indicus \\
\hline
\end{tabular}

Family

Scombridae

Leiognathidae

Clupeidae

Cichilidae

Cichilidae

Chanidae

Mugilidae

Siluridae

Siluridae

Channidae

Channidae

Gobiidae

Lutjanidae

Ariidae

Heteropneustidae

Bagaridae

Scatophagidae

Cyprinidae

Cyprinidae

Cynoglassidae

Portunidae

Palaemonidae

Penaeidae

Penaeidae 
Table.2 Correlation between hydrographical parameters at Panangad-Kumbalam Backwater

\begin{tabular}{|c|c|c|c|c|c|c|c|c|}
\hline \multicolumn{9}{|c|}{ CORRELATION } \\
\hline & Water Temperature & pH & DO & Alkalinity & Transparency & Nitrite & Nitrate & Phosphate \\
\hline $\begin{array}{l}\text { Water } \\
\text { Temperature }\end{array}$ & 1 & $.799^{* * *}$ & $-.627^{* *}$ & .347 & $.516^{*}$ & .411 & $-.540^{*}$ & -.085 \\
\hline pH & & 1 & $-.849^{* *}$ & $.576 *$ & $.494^{*}$ & .371 & $-.540^{*}$ & .016 \\
\hline DO & & & 1 & $-.653^{* *}$ & $-.514^{*}$ & -.314 & $.560^{*}$ & .123 \\
\hline Alkalinity & & & & 1 & .249 & .339 & -.154 & .104 \\
\hline Transparency & & & & & 1 & -.045 & -.230 & .146 \\
\hline Nitrite & & & & & & 1 & .067 & .134 \\
\hline Nitrate & & & & & & & 1 & $.587^{* *}$ \\
\hline Phosphate & & & & & & & & 1 \\
\hline \multicolumn{9}{|l|}{$\mathrm{N}=\mathbf{2 0}$} \\
\hline **. Correlation is & ificant at 0.01 level & -tailed). & & & & & & \\
\hline
\end{tabular}

\section{Phosphate}

The average phosphate was estimated during the study period was $3.16 \mathrm{mmol} / \mathrm{l}$. The highest phosphate was estimated during the first half of February $(4.71 \mathrm{mmol} / \mathrm{l})$ and the lowest phosphate was estimated during the first half of December $(1.9 \mathrm{mmol} / \mathrm{l})$. The maximum average phosphate was recorded during SWmonsoon of $2016(4.14 \mathrm{mmol} / \mathrm{l})$ and the minimum average phosphate was recorded during the post-monsoon $(2.64 \mathrm{mmol} / \mathrm{l})$ (Fig 9). It showed a positive correlation with nitrate $\left(.587^{* * *}\right)$ (Table 2). In the present study maximum nitrate was recorded during the SW-monsoon period and minimum during the NE-monsoon in all the three regions. Nitrate showed decreasing trend during the post monsoon and it continued in NE-monsoon and it showed a slight increase in Premonsoon.

\section{Biological Productivity}

\section{Phytoplankton}

Phytoplankton is a critical component of the marine ecosystem as these organisms are responsible for approximately half the global net primary production (Field et. al., 1998).
Several studies on plankton ecology are available from Cochin backwater (Jyothibabu et. al., 2006; Madhu et. al., 2007; Martin et. al., 2013). The present study was undertaken to observe the diversity of Phytoplankton of Vembanad Lake in the selected region. Diatoms are most dominant species in Panangad-Kumbalam region. Diatoms such as Coscinodiscus sp., Skeletonema costatum., Gymnodinium sp., Fragillaria sp., Pleurosigma sp., Thalassionema Nitzschiodes and Dinoflagillates such as Gymnodinium sp., Ceratium sp. and Alexandrium sp. are present (Fig-10).

\section{Zooplankton}

zooplankton are one of the most important biotic components influencing all the functional aspects of an aquatic system, such as food chain, food webs, energy flow and cycling of organic matter (Nand and Saxena, 1999). In Panangad-Kumbalam region zooplanktons such as Copepods, Cladocera, Rotifer, Fish larvae, Crab Zoea are found during the study period (Fig-11).

\section{Fin and Shell fishes}

The Vembanad Lake is well known to support 
a rich variety of living resource which includes fin and shell fishes. The fishery resource samples obtained were mainly represented by fin fishes, prawns and crabs. The percentage composition analysed with respect to each season samples reveals that while fin fishes invariably dominated in all seasons than the other two groups. Crabs, represented by Scylla serrata were found during the study period in the study region. List of fishes caught from the study region, during the study period are give in table 1 .

\section{Aquatic plants}

During the study period, the common aquatic plants seen in Panangad-Kumbalam was Eichornia crassipes (water-hyacinth), Pistia stratiotes (Water-lettuce), Ceratophyllum demersum (Coon's tail), Hydrilla verticillata (Hydrilla), Azolla (Mosquito fern) and Lemna minor (Duck weed). The observed aquatic plants are dominantly seen during the Postmonsoon and NE-monsoon. During the Premonsoon period, fewer amounts of Eichornia crassipes was seen in Panangad-Kumbalam region. The aquatic plants are seen appearing by the end of south west monsoon.

Many fish processing plants, hotels etc. are situated at both banks of Vembanad Lake. The waste discharges from these establishments, without proper treatment might have deteriorated the quality of water. The present investigation about the PhysicoChemical Characteristics of Vembanad Lake at Panangad-Kumbalam region indicates all the water quality parameters are within the limits. It indicates that there is no pollution in that particular region. Showing all the sewage dumping is effectively treated and released into the water.

\section{Acknowledgement}

The Author is very thankful to Sri. N.N.
Raman, Associate Professor, Aquatic Environment and Management, Kerala University of Fisheries and Ocean Studies, Panangad, Kochi for his timely advice, constructive criticism and thought provoking suggestions throughout the course of my study

\section{References}

APHA. Standard methods for examination of water and waste water, American Public Health Association, Washington, DC, APHAAWWA-WEF, 2005, 167.

Combie, C. A. M, 1953. Factors influencing the growth of phytoplankton. J. Fish. Res. Bd. Can. 10: 153-282.

Devi, S. 2009. Ecology of mangrove patches in the Vembanad Lake at Panangad. M.F.Sc Thesis. Kerala Agriculture University, Thrissur.

Haridevi, C.K., Houlath, K.H., Varma, K.K., Renjith, K.R., Vijaya Kumar, C.T. and Joseph, P. 2004. Seasonal variation of zooplankton in related to Hydrographic parameters in the Panangad region of Vembanad Lake. Proceedings of the national seminar on new frontiers in marine bioscience research, January 22-23, 2004. (eds. Abidi, S.A.H., Ravindran, M., Venkatesan, R. and Vijayakumaran, M.) National Institute of Ocean Technology, Chennai, pp. 501-511.

Jayasree, P. S. 2009. Structural and seasonal changes of the macrobenthic community in relation to the hydrography of a prawn filtration pond. M.F.Sc. Thesis. Kerala Agriicultural University. Thrissur. P. 30-41.

Joseph, M.M., Ratheesh Kumar, C.S., Renjith, K.R., Gireesh Kumar, T.R., and Chandramohana kumar, N. 2011. Phosphorus fractions in the surface sediments of three mangrove systems of sowth west coast of India. Environ. Earth. Sci. 62: 1209-1218.

Jyothibabu, R., Madhu, N.V., Jayalakshmi, K.V., Balachandran, K.K., Shiyas, C.A. and Martin, G.D. 2006. Impact of freshwater influx on microzooplankton mediated food web in a tropical estuary (Cochin backwaters-India). 
Estuarine, Coastal and Shelf Science. 69: 505-518.

Laluraj, C.M., Padma, P., Sujatha, C.H., Nair, S.M., Kumar, N.C. and Chacko. (2002). Base line studies on the chemical constitutes of Kayamkulam Estuary near to the newly commissioned NTPC power station. India. J. Envti. Prtch. 22 (7): 721- 731.

Lynne, M., Witty. 2004. Practical guide to Identifying Freshwater Crustacean zooplankton 2nd edition. http://coopunit.laurentian.com.

Madhu, N.V., Jyothibabu, R., Balachandran, K.K., Honey, U.K., Martin, G.D., Vijay, J.G., 2007. Monsoonal impact on planktonic standing stock and abundance in a tropical estuary (Cochin backwaters India). Estuarine, Coastal and Shelf Science. 73: 54-64.

Manjare, S.A, Vhanalakar, S.A, Muley, D.V. Analysis of water quality using physicochemical parameters Tamdalge tank in Kolhapur district, Maharashtra. Int. J. of Adv. Biotech. and Res. 2010; 1(2): 115-119.

Martin, G.D., Jyothibabu, R., Madhu, N.V., Balachandran, K.K., Maheswari Nair., Muraleedharan, K.R., Arun, P.K., Haridevi, C.K and Revichandran, C. 2013. Impact of eutrophication on the occurrence of Trichodesmium in the Cochin backwaters, the largest estuary along the west coast of India. Environmental Monitoring Assessment. 185(2): 1237-1253.

Menon, M. K. 1951. The life history of bionamics of Indian Penaeid prawn Metapenaeus dobsonii Meirs. Proceedings Indo-Pacific Fish. Count. 3(2\&3): 80-83.

Mogalekar, H.S., Adnankhan Golandaj Ansar, C.P., Raman, N.N. and Devkate Ajinkya. 2015. Temporal Variation in the Hydrobiology of Vembanad Lake at Panangad-Kumbalam Mangrove Patches of
Kochi, Kerala. Research Journal of Animal, Veterinary and Fishery Sciences, 3(3): 1-7.

Nand, D. and Saxena, M.M. 1999. Zooplankton as indicators of trophical status of some desert waters near Bikaner. J. Environ. Poll. 6(8): 251-254.

Pennak, R. W. 1978. Freshwater Invertibrates of the United States, 2nd Ed. New York, John Wiley and Sons. 628p.

Sankaranarayanan, V.N. and Qasim, S.Z. 1969. Nutrients of the Cochin Backwater in relation to environmental characteristics. J. Mar. Biol. 2: $236-247$.

Sarmah, T. D. 2011. Temporal variation in the hydrography and biodiversity of the Cochin backwaters of Puduveypu region. Department of Fishery Hydrography, College of Fisheries, Kerala Agricultural University. PG Thesis.

Silas, E.G. and Parameswaran Pillai, P. 1975. Dynamics of zooplankton in tropical estuary (Cochin backwater) with a review on the plankton fauna of the environment. Bull. Dept. Mar. Sci. University of Cochin. 7(2): 320-355.

Varadharajan, D. and Soundarapandian, P. 2014. Effect of Physicochemical parameters on Species Biodiversity with special reference to the Phytoplankton from Muthupettai, South east coast of India. J. Earth. Sci. Clim. Change. 5: 200

Varma, K.K., Cherian, C.J., Mrithunjayan, P.S., Raman, N.N., and Prabha joseph. 2002. Characterstics of temperature and salinity fluctuations in a south Indian estuary. A study of Vembanad Lake, a monsoon influenced estuary. Earth. Sys. Monitor (NASA). 9-14.

Walmiki, N., Deepti Sharma and Priti Kubal. 2016. Aquatic Diversity with Reference to Phytoplankton, Zooplankton and Benthos in Lake Vembanad, Kottayam, Kerala, India. Res. J. Marine Sci. 4(3): 1- 10.

\section{How to cite this article:}

Jyotsna Rajeswari K., G. Suresh, P. Srikanth and Raman N. N. 2018. Study of Temporal Variations in Physico-Chemical Parameters of Vembanad Lake at Panangad-Kumbalam region, Kochi, Kerala, India. Int.J.Curr.Microbiol.App.Sci. 7(06): 2905-2917.

doi: https://doi.org/10.20546/ijcmas.2018.706.342 